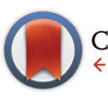

CrossMark \& click for updates

Cite this: Food Funct., 2015, 6, 1875

\section{Nutraceutical properties of the methanolic extract of edible mushroom Cantharellus cibarius (Fries): primary mechanisms}

\author{
Maja Kozarski, ${ }^{\text {a }}$ Anita Klaus, ${ }^{\text {b }}$ Jovana Vunduk, ${ }^{\text {b }}$ Zeljko Zizak, ${ }^{c}$ Miomir Niksic, ${ }^{\text {b }}$ \\ Dragica Jakovljevic, ${ }^{d}$ Miroslav M. Vrvic ${ }^{d, e}$ and Leo J. L. D. Van Griensven* ${ }^{f}$
}

Received 25th March 2015, Accepted 21st April 2015

DOI: $10.1039 / c 5 f o 00312 a$ www.rsc.org/foodfunction
The methanolic extract of the wild edible mushroom Cantharellus cibarius Fr. (chanterelle) was analyzed for in vitro antioxidative, cytotoxic, antihypertensive and antibacterial activities. Various primary and secondary metabolites were found. Phenols were the major antioxidant components found in the extract $\left(49.8 \mathrm{mg} \mathrm{g}^{-1}\right)$, followed by flavonoids, whose content was approximately $86 \%$ of the total phenol content. Antioxidant activity, measured by four different methods, was high for inhibition of lipid peroxidation $\left(E C_{50}=1.21 \mathrm{mg} \mathrm{mL}^{-1}\right)$ and chelating ability $\left(E_{50}=0.64 \mathrm{mg} \mathrm{mL}^{-1}\right)$. The antioxidant activity of the C. cibarius methanol extract was achieved through chelating iron compared to hydrogen atom and/or electron transfer. The extract showed good selectivity in cytotoxicity on human cervix adenocarcinoma HeLa, breast carcinoma MDA-MB-453 and human myelogenous leukemia K562, compared to normal control human fetal lung fibroblasts MRC-5 and human lung bronchial epithelial cells BEAS-2B. The extract had inhibitory activity against angiotensin converting I enzyme (ACE) $\left(I C_{50}=0.063 \mathrm{mg} \mathrm{mL}^{-1}\right)$. The extract revealed selective antimicrobial activity against Gram-positive bacteria with the highest potential against E. faecalis. The medicinal and health benefits, observed in wild C. cibarius mushroom, seem an additional reason for its traditional use as a popular delicacy food.

\section{Introduction}

Wild mushrooms have long been valued as highly nutritious and tasty foods in many societies throughout the world. ${ }^{1,2}$ They are becoming increasingly important in our nutrition due to their composition with high amounts of protein, low total fat level, and the high proportion of polyunsaturated fatty acids (PUFA), making them excellent in low calorie diets. ${ }^{3,4}$ Furthermore, functional food ingredients present in mushrooms are dietary fibers, peptides, lectins, phenolics, terpenes, alkaloids, vitamins and minerals. ${ }^{5,6}$ In addition to their nutri-

\footnotetext{
${ }^{a}$ Department for Chemistry and Biochemistry, Faculty of Agriculture, University of Belgrade, Nemanjina 6, Belgrade 11080, Serbia

${ }^{b}$ Department for Industrial Microbiology, Faculty of Agriculture, University of Belgrade, Nemanjina 6, Belgrade 11080, Serbia

${ }^{c}$ Institute of Oncology and Radiology of Serbia, University of Belgrade, Pasterova 14, Belgrade 11000, Serbia

${ }^{d}$ Institute of Chemistry, Technology and Metallurgy, University of Belgrade, Njegoseva 12, Belgrade 11001, Serbia

${ }^{e}$ Faculty of Chemistry, University of Belgrade, Studentski trg 12-16, 11000 Belgrade, Serbia

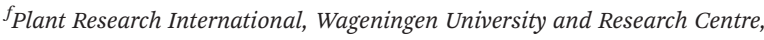

Droevendaalsesteeg 1, Wageningen 6700 AA, The Netherlands.

E-mail: leo.vangriensven@wur.nl; Fax: +31 7 418094; Tel: +31 7480992
}

tional value, many wild edible mushrooms have been investigated for their pharmaceutical constituents. Their antitumor cell, immunomodulatory, antimicrobial, antifungal, and antiviral properties and aspects are now well established facts. ${ }^{7-9}$

The chanterelle Cantharellus cibarius is widely viewed as among the most desirable of wild edible mushrooms. It is probably the best known species of the genus Cantharellus, if not of the entire family of Cantharellaceae. C. cibarius is world famous not only as delicious food but also because of its appearance from Scandinavia to the Mediterranean in Europe.$^{10}$ It is a mycorrhizal fungus that grows at different altitudes, with different kinds of trees, both in the lowlands (often with beech), and in the mountains (grows in clusters in mossy spruce and fir forests) where it can be found up to 1600 meters above the sea level. It is known as the Girolle in France, Capo gallo in Italy, Yumurta mantari in Turkey, and simply as Chanterelle or Golden chanterelle in Britain. ${ }^{10,11}$ Orange or yellow, it is highly appreciated for its wonderful fruity, apricot like aroma, being particularly prized for cooking throughout Europe. It can be used in risotto dishes and omelettes, and it certainly has enough flavor to make tasty soups or sauces to be served with chicken or fish dishes. ${ }^{12}$ Despite the fact that C. cibarius is a very good widespread edible mushroom, it has been very difficult to cultivate. One reason seemed the pres- 
ence of bacteria and other foreign microorganisms within the sporocarp tissues. ${ }^{10}$ Like most mycorrhizals, however, C. cibarius cannot be cultivated without its host. ${ }^{11}$ After many years of unsuccessful efforts to cultivate Chanterelle, Danell and Camacho $^{13}$ reported some early success, but almost two decades later cultivation techniques are still under development.

Fruiting bodies of C. cibarius from different habitats have been analyzed for their levels of carbohydrates, proteins, lipids, vitamins and minerals. ${ }^{10,14,15}$ Analyses based on the nutritional value (by $100 \mathrm{~g}$ fresh weight) reveal that $C$. cibarius has a low fat $(0.53 \mathrm{~g})$ and low energy $(160 \mathrm{~kJ})$ content. ${ }^{16}$ It presents various vitamins, namely thiamin, niacin, pantothenic acid, riboflavin, ascorbic acid, and is among the richest sources of vitamin D known, with ergocalciferol (vitamin $\mathrm{D}_{2}$ ) as high as $212 \mathrm{IU}$ per $100 \mathrm{~g}$ fresh weight. ${ }^{16}$ Scientists suggested that $C$. cibarius may have potent insecticidal properties that are harmless to humans and yet protect the mushroom body against insects and other potentially harmful organisms. ${ }^{17}$ Besides, C. cibarius has been reported as a source of phytochemicals and antioxidants with potential medicinal values. $^{14,18}$

Herein, we present a study of the chemical composition and biological properties of the methanolic extract of the wild mushroom Cantharellus cibarius found in Durmitor, a national park in northwestern Montenegro, in order to assess this natural source of nutrients and nutraceuticals. Chemical analysis included preliminary phytochemical screening of the mushroom extract and determination of phenolics, flavonoids, carotenoids, lycopene, ascorbic acid, and carbohydrates and protein quantities. We also used Fourier transform infrared (FT-IR) and Ultra Violet-Visible (UV-VIS) spectroscopy for further analysis of its chemical composition. Biological characterization was focused on the in vitro evaluation of mushroom extract bioactive properties such as antioxidant, antimicrobial, cytotoxic activities and for the first time angiotensin-converting enzyme (ACE) inhibition.

\section{Materials and methods}

\subsection{Chemicals}

Dimethylsulfoxide (DMSO), Angiotensin Converting Enzyme (ACE) from rabbit lung [EC 3.4.15.1], 1,1-diphenyl-2-picrylhydrazyl (DPPH), linoleic acid, 3-(4,5-dimethylthiazol-2-yl)-2,5diphenyltetrazolium bromide (MTT), Dragendorff's and Mayer's reagent, Fast Blue BB diazonium dye, ferric chloride, potassium ferricyanide, ferrozine, ferrous chloride, standards such as D-Glucose (D-Glc; anhydrous, 99.5\% min), $\alpha$-tocopherol, ascorbic acid, citric acid, ethylenediaminetetraacetic acid (EDTA), (+)-catechin, gallic acid, bovine serum albumin (BSA, 98\% electrophoresis purity), hippuryl--L-histidyl-L-leucine (HHL) and captopril, RPMI-1640, fetal bovine serum (FBS), Hepes, streptomycin, penicillin and L-glutamine were purchased from Sigma Chemical Co. (St. Louis, MO, USA) and Merck Co. (Darmstadt, Germany). 2,3,5-Triphenyl tetrazolium chloride (TTC) was procured from Aldrich Chemical Company Inc. USA. Absolute methanol (Methanol Optigrade) was provided by LGC Promochem, Germany. All other chemicals and reagents were either extra pure or of analytical reagent grade. Microbiological media were purchased from Merck Millipore (Darmstadt, Germany).

\subsection{Fruiting body selection}

Wild fruiting bodies of Cantharellus cibarius Fr. (chanterelle) were harvested in summer 2013 in mossy Abies alba forests, among grasses and low-growing herbs (Fig. 1), in a national park, Durmitor (Montenegro), a protected territory under The United Nations Educational, Scientific and Cultural Organization (UNESCO) designations. ${ }^{19}$ After collection, carpophores were identified according to the methods of classical herbarium taxonomy to confirm correct species, ${ }^{20}$ then brushcleaned, air-dried at $40{ }^{\circ} \mathrm{C}$ to constant mass and ground into fine particles by a Cyclotec mill (Tecator, Hoganas, Sweden) through $0.5 \mathrm{~mm}$ sieves into powder (40 mesh), which was then stored in the dark prior to analysis. ${ }^{21}$ The representative voucher specimens and their mycelial cultures were deposited at the herbarium of the Department for Industrial Microbiology (University of Belgrade-Faculty of Agriculture) in the culture collection for mushrooms.

\subsection{Sample preparation}

The fruiting bodies were lyophilized (LyoAlfa 15-85, Telstar, Spain) and powdered before analysis. The methanolic extract was obtained according to the method of Barros et al. ${ }^{22}$ with slight modifications. The dry sample (10 g) was extracted by stirring with $200 \mathrm{~mL}$ of methanol at $120 \mathrm{rpm}$ for $24 \mathrm{~h}$ and filtered through Whatman No. 4 paper. The residue was then extracted with two additional $200 \mathrm{~mL}$ portions of methanol, as described earlier. The combined methanolic extracts were

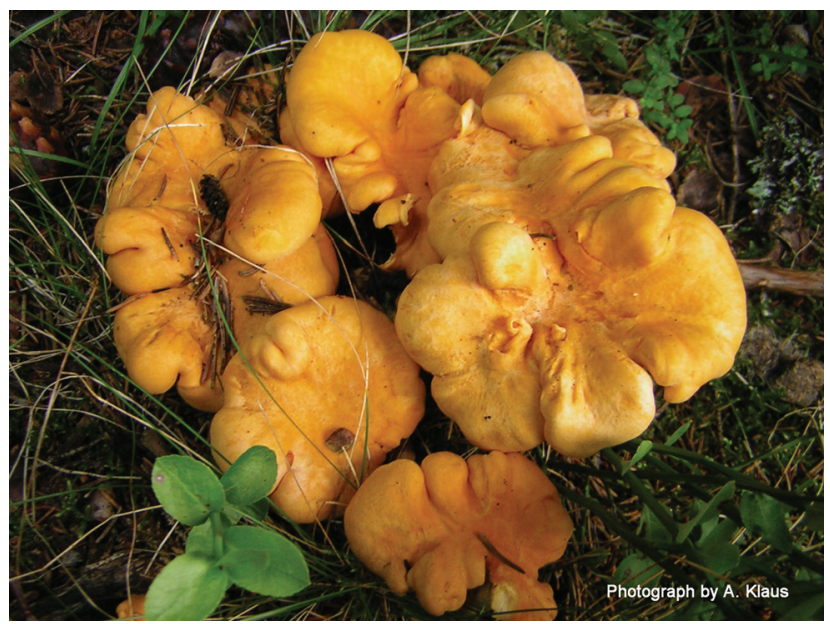

Fig. 1 Cantharellus cibarius Fr. (chanterelle). Cantharellus cibarius Fries (Cantharellaceae), higher Basidiomycetes, growing in clusters in mossy Abies alba forests, among grasses and low-growing herbs like Vaccinium myrtillus L. and Hypericum perforatum L. (Durmitor, Montenegro). 
evaporated at $40{ }^{\circ} \mathrm{C}$ to dryness (Buchi Rotavapor ${ }^{\circledR}$ R II) and stored at $4{ }^{\circ} \mathrm{C}$ for further use.

\subsection{Phytochemical screening}

The preliminary phytochemical screening of the mushroom extract was carried out by using the methods of Kokate ${ }^{23}$ and Harborne. ${ }^{24}$ The following phytochemicals and tests were evaluated: glycosides by Keller-Kiliani's, sterols by LiebermannBurchard's, phenols after addition of ferric chloride solution, and flavonoids by using magnesium turnings. Tannins were observed by lead-acetate test, alkaloids by using Dragendorff's and Mayer's reagent separately, and detection for free anthraquinone was done by Borntrager's test. The presence of terpenoids was observed by using Salkowski test, after addition of chloroform, and few drops of concentrated $\mathrm{H}_{2} \mathrm{SO}_{4}$. Each analysis was carried out in five replications.

\subsection{Determination of polysaccharide and protein content}

The total polysaccharide content of the extract was determined using the phenol-sulfuric acid method with D-Glc as a reference. $^{25}$ The standard curve was drawn using $62.5-500 \mu \mathrm{g} \mathrm{mL}$ of Glc and the results are expressed as $\mathrm{mg}$ of Glc equivalents per $g$ of DW of the extract.

Protein concentration was determined by Bradford ${ }^{26}$ and BSA (0.1-1.0 $\mathrm{mg} \mathrm{mL}^{-1}$ ) was used to produce a standard calibration curve. The total protein content of the extracts was expressed as $\mathrm{mg}$ of BSA equivalents per $1 \mathrm{~g}$ of DW of the extract.

\subsection{Determination of phytochemical content}

The total phenolic (TP) content was determined using a recently developed Fast Blue BB (FBBB) method. ${ }^{27}$ The C. cibarius methanol extract was diluted one time with DMSO. ${ }^{28,29}$ The TP analysis consisted of adding $0.1 \mathrm{~mL}$ of $0.1 \%$ Fast Blue BB diazonium dye to $1 \mathrm{~mL}$ sample followed by the addition of $0.1 \mathrm{~mL}$ of $5 \% \mathrm{NaOH}$. After $90 \mathrm{~min}$ reaction time, the absorbance was measured at $420 \mathrm{~nm}$ with a UV/Vis spectrophotometer (Shimadzu UV-1650 PC, Japan). The standard curve

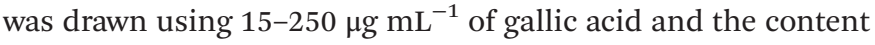
of total phenols was expressed as gallic acid equivalents (GAE) per $g$ of DW of the extract.

The flavonoid content in the extract was determined by a colorimetric method described by Jia et al. ${ }^{30}$ with some modifications of Barros et al. ${ }^{22}$ The mushroom extract $(250 \mu \mathrm{L})$ was mixed with $1.25 \mathrm{~mL}$ of Milli-Q water (MQ) and $75 \mu \mathrm{L}$ of a $5 \%$ $\mathrm{NaNO}_{2}$ solution. After $5 \mathrm{~min}, 150 \mu \mathrm{L}$ of a $10 \% \mathrm{AlCl}_{3}$ solution was added. After $6 \mathrm{~min}, 500 \mu \mathrm{L}$ of $1 \mathrm{M} \mathrm{NaOH}$ and $275 \mu \mathrm{L}$ of MQ were added to the mixture. The solution was mixed well and the intensity of pink colour was measured at $510 \mathrm{~nm}$ using a UV/Vis spectrophotometer (Shimadzu UV-1650 PC, Japan). (+)-Catechin was used to calculate the standard curve $(0.022-0.34 \mathrm{mM})$ and the results are expressed as $\mathrm{mg}$ of $(+)$-catechin equivalents (CEs) per $\mathrm{g}$ of extract.

Ascorbic acid was determined according to the method of Klein \& Perry. ${ }^{31}$ The dried methanolic extract $(100 \mathrm{mg})$ was extracted with $10 \mathrm{~mL}$ of $1 \%$ metaphosphoric acid for $45 \mathrm{~min}$ at room temperature and filtered through Whatman No. 4 filter paper. The filtrate $(1 \mathrm{~mL})$ was mixed with $9 \mathrm{~mL}$ of 2,6-dichlorophenolindophenol and the absorbance was measured within $30 \mathrm{~min}$ at $515 \mathrm{~nm}$ against a blank. The content of ascorbic acid was calculated on the basis of the calibration curve of authentic L-ascorbic acid (20-250 $\left.\mu \mathrm{g} \mathrm{mL}^{-1}\right)$ and the result was expressed as mg of ascorbic acid per $\mathrm{g}$ of the extract.

$\beta$-Carotene and lycopene were determined according to the method of Nagata \& Yamashita. ${ }^{32}$ The dried methanolic extract (100 mg) was vigorously shaken with $10 \mathrm{~mL}$ of an acetonehexane mixture $(4: 6)$ for $1 \mathrm{~min}$ and filtered through Whatman No. 4 filter paper. The absorbance of the filtrate was measured at 453, 505 and $663 \mathrm{~nm}$. Contents of $\beta$-carotene and lycopene were calculated according to the following equations: lycopene $(\mathrm{mg}$ per $100 \mathrm{~mL})=-0.0458_{\mathrm{A} 663}+0.372_{\mathrm{A} 505}-0.0806_{\mathrm{A} 453} ; \beta$-carotene $(\mathrm{mg}$ per $100 \mathrm{~mL})=0.216_{\mathrm{A} 663}-0.304_{\mathrm{A} 505}+0.452_{\mathrm{A} 453}$. The results are expressed as $\mu \mathrm{g}$ of carotenoid $\mathrm{g}^{-1}$ of the extract.

\subsection{FT-IR and UV-VIS extract analyses}

The crude methanol extract from $C$. cibarius contained a part that was hardly soluble in methanol, and could possibly contain some bound phenolic compounds. Therefore, the crude extract was subjected to alkaline hydrolysis as described by Hung \& $\mathrm{Nhi}^{33}$ with some modifications. The whole crude extract was saponificated with $2 \mathrm{M} \mathrm{NaOH}$, then acidified to pH 2 with $4 \mathrm{M} \mathrm{HCl}$, after which the solution was evaporated to dryness and the residue was dissolved in pure methanol.

2.7.1. FT-IR spectroscopy. The FT-IR spectrum was obtained using a Fourier transform infrared spectrophotometer Thermo-Nicolet Model 6700 (Thermo Scientific, USA), equipped with Smart Orbit (Diamond) ATR accessory and OMNIC 7.3 software, in the $4000-400 \mathrm{~cm}^{-1}$ range at a resolution of $4 \mathrm{~cm}^{-1}$ in transmission mode.

2.7.2. UV-VIS spectroscopy. The UV-Vis spectrum was recorded on an UV-Vis spectrophotometer GBC Cintra 40. The spectrum was recorded in a spectral range between 225 and $550 \mathrm{~nm}$.

\subsection{Evaluation of the antioxidant properties}

For measuring antioxidant activity in vitro, different methods, corresponding to different levels of antioxidant action, were used. ${ }^{34}$ The radical absorbance ability of the $C$. cibarius methanolic extract using the DPPH free radical-scavenging capability, inhibition of lipid peroxidation in the linoleic acid model system and the ferric $\left(\mathrm{Fe}^{3+}\right)$ reducing antioxidant power assay were compared. Also, the chelating ability of ferrous ions $\left(\mathrm{Fe}^{2+}\right)$ of the investigated extract was observed according to the method of Dinis et al. ${ }^{35}$ with slight modifications. ${ }^{34}$

For each method the extract was analyzed at a concentration range of (0.01-10 $\left.\mathrm{mg} \mathrm{mL}^{-1}\right)$. The results are normalized and expressed as median effective concentrations, i.e. $\mathrm{EC}_{50}(\mathrm{mg}$ $\mathrm{mL}^{-1}$ ) values, which are the effective concentrations of the mushroom extract that are required to show 50\% antioxidant properties. A lower $\mathrm{EC}_{50}$ value corresponds to higher antioxidant activity of the mushroom extract. Each extract was ana- 
lyzed in five replicates for each antioxidant test, and the results are reported as mean values \pm standard deviation.

\subsection{Cytotoxicity analysis}

Stock solution of the $C$. cibarius extract was prepared in DMSO

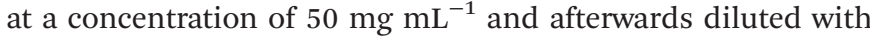
complete nutrient medium (RPMI-1640) supplemented with $3 \mathrm{mM}$ L-glutamine, $100 \mu \mathrm{g} \mathrm{mL} \mathrm{m}^{-1}$ streptomycin, $100 \mathrm{IU} \mathrm{mL}$ penicillin, $10 \%$ heat inactivated fetal bovine serum (FBS) and $25 \mathrm{mM}$ Hepes, and adjusted to $\mathrm{pH} 7.2$ by a bicarbonate solution. Human cervix adenocarcinoma HeLa, breast carcinoma MDA-MB-453, human fetal lung fibroblasts MRC-5 and human lung bronchial epithelial cells BEAS-2B cells were cultured as monolayers in nutrient medium, while human myelogenous leukemia K562 cells were maintained as a suspension culture. The cells were grown at $37^{\circ} \mathrm{C}$ in $5 \% \mathrm{CO}_{2}$ and a humidified air atmosphere.

HeLa (2000 cells per well), MDA-MB-453 (3000 cells per well), MRC-5 (5000 cells per well) and BEAS-2B (5000 cells per well) cells were seeded into 96-well microtiter plates and $20 \mathrm{~h}$ later, after the cell adherence, five different concentrations of the extract were added to the wells. Final concentrations were in the range from 0.0625 to $1 \mathrm{mg} \mathrm{mL}^{-1}$. Only nutrient medium was added to the cells in the control wells. The investigated extract was added to a suspension of leukemia K562 cells (5000 cells per well) $2 \mathrm{~h}$ after cell seeding, in the same final concentrations. All experiments were done in five replications. Nutrient medium with the corresponding concentrations of compounds, but void of cells was used as a blank.

Cell survival was determined by the MTT test according to the method of Mosmann ${ }^{36}$ and modified by Ohno and Abe, ${ }^{37}$ 72 hours after the investigated extract was added. Briefly, $20 \mu \mathrm{L}$ of MTT solution ( $5 \mathrm{mg} \mathrm{mL} \mathrm{m}^{-1}$ in phosphate buffered saline) was added to each well. Samples were incubated for further four hours at $37{ }^{\circ} \mathrm{C}$ under a humidified atmosphere with $5 \% \mathrm{CO}_{2}$. Then, $100 \mu \mathrm{L}$ of $10 \%$ sodium dodecyl sulfate (SDS) was added to the wells. Absorbance was measured at $570 \mathrm{~nm}$ the next day. To achieve cell survival (\%), absorbance at $570 \mathrm{~nm}$ of a sample was divided by the absorbance of the control sample (the absorbance of cells grown only in nutrient medium), after subtraction of absorption of the blank. Concentrations of the extract which induced a 50\% decrease in malignant and normal cell survival ( $\mathrm{IC}_{50}$ values) were calculated from a doseresponse growth curve with Microsoft ${ }^{\circledR}$ Excel ${ }^{\circledR} 2013$ software.

\subsection{ACE inhibitory activity assay}

2.10.1. ACE activity assay. The following method is based on the method described by Hernandez-Ledesma et al. ${ }^{38}$ with some modifications. $25 \mu \mathrm{L}$ of ACE $\left(26 \mathrm{mU} \mathrm{mL}^{-1}\right)$ dissolved in glycerol $(50 \%)$ was incubated with $15 \mu \mathrm{L}$ of $\mathrm{MQ}$ water at $37{ }^{\circ} \mathrm{C}$ for $10 \mathrm{~min}$. After the addition of $110 \mu \mathrm{L}$ of $10 \mathrm{mM}$ HHL dissolved in a pH 8.3 $0.2 \mathrm{M}$ phosphate buffer with $0.3 \mathrm{M} \mathrm{NaCl}$, the reaction solution was incubated at $37^{\circ} \mathrm{C}$ for $80 \mathrm{~min}$. ACE activity was stopped by a decrease in $\mathrm{pH}$ by addition of $110 \mu \mathrm{L}$ of $1 \mathrm{M} \mathrm{HCl}$. The hippuric acid formed in the enzymatic process was extracted with $1 \mathrm{~mL}$ of ethyl acetate, shaken, and later centrifuged at $3000 \mathrm{~g}$ for $10 \mathrm{~min} .750 \mu \mathrm{L}$ of the organic layer was taken and dried out at $95{ }^{\circ} \mathrm{C}$ for $30 \mathrm{~min}$. The residue, hippuric acid, was redissolved in $1 \mathrm{~mL}$ of MQ water, and the absorbance was measured at $228 \mathrm{~nm}$.

The reaction blank was prepared by adding the $\mathrm{HCl}$ before adding the enzyme. No incubation is then needed. ${ }^{38}$

2.10.2. ACE-inhibitory activity. The inhibition percentage of the $C$. cibarius methanol extract was determined using the conditions selected in this study, replacing $15 \mu \mathrm{L}$ of water with the same volume of the sample to be studied. The dried extract was redissolved in $10 \% \mathrm{DMSO}^{39,40}$ before analysis at a concentration range of $0.005-5 \mathrm{mg} \mathrm{mL}^{-1}$. The determinations were carried out in five replications.

When the sample contained substances that could interfere, it was necessary to determine their absorbance and apply the formula provided in this study. ${ }^{38}$ The sample blank was prepared in the same way as the reaction blank, replacing the volume of water by the sample.

The ACE inhibition percentage was calculated using the following equation:

$$
\% \text { IACE }=100[(A-B)-(C-D)] /(A-B)
$$

where $A$ represents absorbance in the presence of ACE, $B$ absorbance of the reaction blank, $C$ absorbance in the presence of ACE and inhibitor, and $D$ absorbance of the sample blank. ${ }^{38}$

\subsection{Antimicrobial activity testing}

Four Gram-positive (Staphylococcus aureus ATCC 25923, Enterococcus faecalis ATCC 29212, Bacillus cereus ATCC 10876, Listeria monocytogenes ATCC 19115) and five Gram-negative bacterial species (Escherichia coli ATCC 25922, Salmonella enteritidis ATCC 13076, Shigella sonnei ATCC 29930, Yersinia enterocolitica ATCC 27729, Escherichia coli (O157:H7) ATCC 12900) were challenged in this study to ascertain the antibacterial properties of C. cibarius. Selected species of bacteria originate from ATCC (American Type Culture Collection, Rockville, Maryland). These microorganisms were chosen for the bioassay because of their well known food spoilage and pathogenic characteristics. Each species was maintained on a Mueller-Hinton agar (MHA) plate which was also used to confirm the absence of contamination and the validity of the inocula. Before testing every species was recovered by sub-culturing in MuellerHinton broth (MHB), aerobically, for $24 \mathrm{~h}$, at $37^{\circ} \mathrm{C}$. Working concentrations of approximately $10^{5}-10^{6} \mathrm{cfu} \mathrm{mL}^{-1}$ used for antibacterial activity assays were prepared by appropriate dilution of culture in microbiological medium.

The C. cibarius methanol extract was dissolved in DMSO (2\%) to prepare stock solutions at a concentration of $80 \mathrm{mg}$ $\mathrm{mL}^{-1}$, sterilized by filtration through a $0.22 \mu \mathrm{m}$ membrane filter (Sartorius, Germany) according to Tepe et $a l^{88}$ and further diluted in MHB to working solutions. DMSO was chosen as a non-toxic solvent.

2.11.1. Disk diffusion method. The disk diffusion assay was done according to CLSI, ${ }^{41}$ with some modifications. Each bacterial culture (approximately $10^{5}-10^{6} \mathrm{cfu} \mathrm{mL}^{-1}$ ) was added 
(0.1 mL) to Petri dishes $(90 \mathrm{~mm})$ containing MHA $(20 \mathrm{~mL})$. Three sterile blank paper disks $(6 \mathrm{~mm}$ in diameter, Susceptibility Test Discs, SD 067-5CT, HiMedia) were placed on the surface of each agar plate and inoculated with $50 \mu \mathrm{L}$ of the mushroom extract $\left(20 \mathrm{mg} \mathrm{mL}^{-1}\right)$. After $2 \mathrm{~h}$ at $25^{\circ} \mathrm{C}$, the plates were incubated aerobically, for $24 \mathrm{~h}$ at $37{ }^{\circ} \mathrm{C}$. After the incubation period, the inhibition zone $(\mathrm{mm})$ was measured including the initial diameter of the disk. Tests were performed in five repetitions and the results were analyzed for statistical significance.

The plates with MHA were sterility controls. Negative controls were disks impregnated with DMSO. Positive controls were disks (Sigma-Aldrich GmbH, Steinheim, Germany) with gentamicin $(30 \mu \mathrm{g})$ and tetracycline $(30 \mu \mathrm{g})$.

2.11.2. Broth microdilution method. The broth microdilution method was employed to determine minimum inhibitory (MIC) and minimum bactericidal (MBC) concentrations. ${ }^{41,42}$ Concentrations of the mushroom extract ranged from 0.0097 to $20.0 \mathrm{mg} \mathrm{mL}{ }^{-1}$. Test bacterial culture $(50 \mu \mathrm{L})$ in $\mathrm{MHB}$ was added to the wells of a sterile 96-well microtiter plate (Sarstedt, Germany) already containing $50 \mu \mathrm{L}$ of the two-fold serially diluted extract in MHB. The final volume in each well was $100 \mu \mathrm{L}$. The microplates were prepared in triplicate and incubated aerobically, for $24 \mathrm{~h}$ at $37^{\circ} \mathrm{C}$. Sterility controls were wells with MHB. Negative controls were wells with mushroom extracts in $50 \mu \mathrm{L}$ of MHB. Positive controls were wells with a bacterial suspension in $50 \mu \mathrm{L}$ of $\mathrm{MHB}$ and wells with a bacterial suspension in MHB with DMSO in amounts corresponding to the highest quantity present in the broth microdilution assay (to prove that DMSO had no inhibition effect on the bacterial growth). A microplate shaker (Lab Companion, VM-96B, Korea) was used for mixing the content of each well at $900 \mathrm{rpm}$ for $1 \mathrm{~min}$ prior to incubation under the cultivation conditions described above.

To indicate cellular respiration, TTC was added to the culture medium. The final concentration of TTC after inoculation was $0.05 \%$. Viable microorganisms enzymatically reduced the colorless compound in TTC to a pink TPF $(1,3,5$ triphenylformazan). The MIC was defined as the lowest sample concentration that prevented this change and exhibited complete inhibition of bacterial growth. MBC was determined by serial sub-cultivation of $50 \mu \mathrm{L}$ from each well that showed no change in colour into microplates containing $50 \mu \mathrm{L}$ of MHB. The microplates were incubated aerobically, for $24 \mathrm{~h}$ at $37^{\circ} \mathrm{C}$. The lowest concentration of the extract without any visible growth after this sub-culturing was considered as minimum bactericidal concentration (MBC).

\subsection{Statistical analysis}

All determinations of antioxidant, cytotoxic, antibacterial and ACE-inhibitory activities were done in five repetitions. The results are reported as mean \pm standard error of the mean (SEM). Statistical analyses were done using MS Excel (Microsoft Office 2007 Professional). Calculation of $\mathrm{EC}_{50}$ values was done by linear regression analyses using free statistical regression calculations online. ${ }^{43}$

\section{Results and discussion}

\subsection{Preliminary screening of secondary metabolites}

Following the methanol extraction, the results of the phytochemical screening of the $C$. cibarius extract are presented in Table 1. Different types of secondary metabolites such as phenols, flavonoids, terpenoids, sterols, glycosides, anthraquinones and tannins were present while no alkaloids were detected.

The phytochemical composition of the C. cibarius methanolic extract from a different country $^{44}$ has already been described. Aina et $a l .{ }^{44}$ reported that the methanolic extract of C. cibarius obtained from the Oyingbo market in Lagos (Nigeria) contained flavonoids, alkaloids, anthraquinones, terpenoids, saponin and phenols, while the presence of tannins, phlobatannins, and steroids was not confirmed.

Despite some similarities in the composition of African and European $C$. cibarius extracts, it is known that the chemical compositions of mushrooms are affected by a number of factors, namely, mushroom strain/type, composition of growth media, time of harvest, management techniques, handling conditions, and preparation of the substrates. ${ }^{45}$

Moreover, stress conditions such as UV radiation, infection by pathogens and parasites, wounding, air pollution and exposure to extreme temperatures have significant effects on the levels and quality of the phytochemicals in mushroom species. $^{46,47}$

\subsection{Carbohydrate, protein and phytochemical content}

The results of the carbohydrate, protein and selected phytochemical content (expressed on dry weight basis) obtained for the investigated extract are shown in Table 2.

Phenols were the major components found in the extract (49.8 $\mathrm{mg} \mathrm{g}^{-1}$ ), followed by flavonoids, whose content was approximately $86 \%$ of the total phenol content. Grangeia et $a{ }^{3}{ }^{3}$ by using Folin-Ciocalteu's method, reported that the total phenol content in the methanolic extracts of different saprotrophic and mycorrhizal wild edible mushrooms was in the range of 22-48 $\mathrm{mg} \mathrm{GAE} \mathrm{g}^{-1}$ DW extract.

Barros et al. ${ }^{14}$ reported $1.75 \mathrm{mg}$ GAE $\mathrm{g}^{-1}$ of total phenols detected by the Folin-Ciocalteu method and $0.47 \mathrm{mg} \mathrm{g}^{-1}$ of

Table 1 Phytochemicals of the methanol extract from C. cibarius ${ }^{a}$

Phytochemicals

Glycosides

Phenols

Flavonoids

Sterols

Tannins

Alkaloids

Anthraquinones

Terpenoids

${ }^{a}(-)$ indicates the absence of phytochemical, $(+)$ indicates the presence of phytochemical. 
Table 2 Content of carbohydrates, proteins and selected phytochemicals of the methanol extract from $C$. cibarius expressed as the dry weight of the extract (mean \pm SEM)

C. cibarius methanol extract

\begin{tabular}{lr}
\hline Carbohydrates $\left(\mathrm{mg} \mathrm{g}^{-1}\right)$ & $30.4 \pm 0.9$ \\
Proteins $\left(\mathrm{mg} \mathrm{g}^{-1}\right)$ & $9.3 \pm 0.7$ \\
Phenols $\left(\mathrm{mg} \mathrm{g}^{-1}\right)$ & $49.8 \pm 1.6$ \\
Flavonoids $\left(\mathrm{mg} \mathrm{g}^{-1}\right)$ & $42.9 \pm 2.0$ \\
Ascorbic acid $\left(\mathrm{mg} \mathrm{g}^{-1}\right)$ & $1.0 \pm 0.1$ \\
$\beta$-Carotene $\left(\mu \mathrm{g} \mathrm{g}^{-1}\right)$ & $194.5 \pm 5.1$ \\
Lycopene $\left(\mu \mathrm{g} \mathrm{g}^{-1}\right)$ & $112.2 \pm 2.9$
\end{tabular}

flavonoids on the DW of the Portuguese wild C. cibarius methanol extract. The same research group ${ }^{47}$ showed that no phenolic acids were detected in C. cibarius.

Valentao et $a l .{ }^{18}$ identified the presence of six phenolic compounds (3-,4- and 5-O-caffeoylquinic acid, caffeic acid, $p$-coumaric acid and rutin) and five organic acids (citric, ascorbic, malic, shikimic and fumaric acids) in wild Cantharellus cibarius from the northeastern region of Portugal. The existence of chemical variability within the species cannot be excluded considering that, as each individual may result from the cross-breeding of different hyphae, each mushroom could represent a distinct genotype.$^{18}$ On the other hand, the loss of water also increased phenol oxidase activity of phenolic compounds, which are oxidized to quinones and form brown/black melanin pigments. ${ }^{18}$

Phenolic compounds include different subclasses (flavonoids, phenolic acids, stilbenes, lignans, tannins, oxidized polyphenols) displaying a large diversity of structures, some of which may escape the usual methodologies of analysis. ${ }^{48}$

The Folin-Ciocalteu reagent has been widely used for many years in measuring total phenolics. However, this method has been criticized for its lack of specificity since several non-phenolic substances such as ascorbic acids, amino acids and sugars can interfere with the TP measurement. ${ }^{14,27}$ In addition, the results have to be expressed in equivalents of a particular standard compound (like catechin, gallic acid or tannin acid). All these aspects make the results obtained from different authors difficult to compare.

FBBB, a recently developed, simple, rapid, and direct detection of phenolics in foods, beverages, and agricultural byproducts, was also used to measure TP. ${ }^{27}$ It is based on the coupling of phenolic compounds with the Fast Blue BB diazonium salt resulting in the formation of azo complexes where coupling mostly occurs at the para position to the phenolic activating group. Coupling or substitution may also occur at the ortho position to the activating group. Phenolics in slightly alkaline solution are converted to the more active phenoxide ions, allowing the coupling to occur. ${ }^{27}$ Therefore, in this study we opted for the detection of the phenol content by using the FBBB method.

Ascorbic acid was found in an amount of $1 \mathrm{mg} \mathrm{mL}^{-1}$ (Table 2), approximately 2.5 times more than in the methanol extract of wild Portuguese C. cibarius. ${ }^{14}$ Grangeia et al. ${ }^{3}$ found high concentrations of ascorbic acid in the methanolic extracts of different saprotrophic and mycorrhizal wild edible mushrooms. The highest ascorbic acid concentration was found in the saprotrophic mushroom Clitopilus prunulus (400.36 mg per $100 \mathrm{~g} \mathrm{DW}$ ), while the lowest value was found in the mycorrhizal mushroom Boletus fragrans (81.32 mg per $100 \mathrm{~g}$ DW).

$\beta$-Carotene and lycopene were found in significantly higher concentrations (Table 2) than the $\beta$-carotene $(5.77 \pm 0.41 \mu \mathrm{g}$ $\left.\mathrm{g}^{-1}\right)$ and lycopene $\left(1.95 \pm 0.28 \mu \mathrm{g} \mathrm{g}^{-1}\right)$ content of the wild Portuguese C. cibarius methanol extract. ${ }^{14}$

Carbohydrates were expected in the extract (Tables 1 and 2). Bioactive phenol and flavonoid glycosides were reported in many fungal species. ${ }^{49,50-52} \mathrm{Kim}$ et al. ${ }^{53}$ isolated $\beta$-sitosterol glucoside from the methanol extract of $C$. cibarius.

The protein content in the methanol extract was $9.3 \mathrm{mg} \mathrm{g}^{-1}$ (Table 2). The methanol-soluble proteins are known to specifically contribute to the production of flavor. ${ }^{54-56}$ Mildly savory or "umami" taste of mushrooms is the taste quality usually represented by amino acids, or proteins. ${ }^{55}$ Cantharellus cibarius is comprised of $10 \%$ protein..$^{57}$ One amino acid in particular, glutamate, was found to be present in high concentrations. ${ }^{58}$ High levels of glutamate were reported in several commercially available mushrooms Lentinula edodes, Pleurotus ostreatus, and Agaricus bisporus, alongside other foods that are traditionally considered rich in amino acids and are good examples of "umami" foods..$^{55}$

\subsection{FT-IR and UV-VIS extract analyses}

The FT-IR spectrum of the C. cibarius methanolic extract contained absorption bands characteristic for the functional groups of the components that are present (Fig. 2). The strong broad band at $3384 \mathrm{~cm}^{-1}$ was assigned to the presence of $\mathrm{OH}$ stretching in hydrogen bonds and $\mathrm{N}-\mathrm{H}$ vibration. Absorption peaks between 2950 and $2850 \mathrm{~cm}^{-1}$ correlated to stretching frequencies of aliphatic $\mathrm{C}-\mathrm{H}$ groups. Absorption peaks at $2928 \mathrm{~cm}^{-1}$ and $2855 \mathrm{~cm}^{-1}$ suggested aliphatic C-H asymmetric and symmetric stretching vibrations, respectively, and the peak at $3010 \mathrm{~cm}^{-1}$ was related to the presence of the stretching frequencies of an aliphatic methyl group. In addition, the peak at $1430 \mathrm{~cm}^{-1}$ was also due to aliphatic groups. This spectrum showed an absorption band at $1739 \mathrm{~cm}^{-1}$ that was indicative for stretching frequencies of an esterified $\mathrm{C}=\mathrm{O}$ group, and the band at about $1690 \mathrm{~cm}^{-1}$ was indicative for asymmetric vibrations of the carboxylic group. The absorption peak at $1585 \mathrm{~cm}^{-1}$ showed the presence of phenolic $\mathrm{C}=\mathrm{C}$ stretching vibrations. This intensive peak was overlapped by a corresponding $\mathrm{C}-\mathrm{C}$ stretching vibration of the polyene chain of chromophore at $1550 \mathrm{~cm}^{-1}$.

The peak at $1400 \mathrm{~cm}^{-1}$ correlated to stretching frequencies of OH groups of phenolic compounds. The peak at $1240 \mathrm{~cm}^{-1}$ indicated aromatic $(\mathrm{C}-\mathrm{O}-\mathrm{C})$ frequencies and overlapped with absorption frequency of C-N stretching. Peaks at 1078, 1050, 1022 , and $930 \mathrm{~cm}^{-1}$ correlated to $\mathrm{C}-\mathrm{O}-\mathrm{C}$ linkages of sugar components which were remaining in the extract. ${ }^{59}$ 


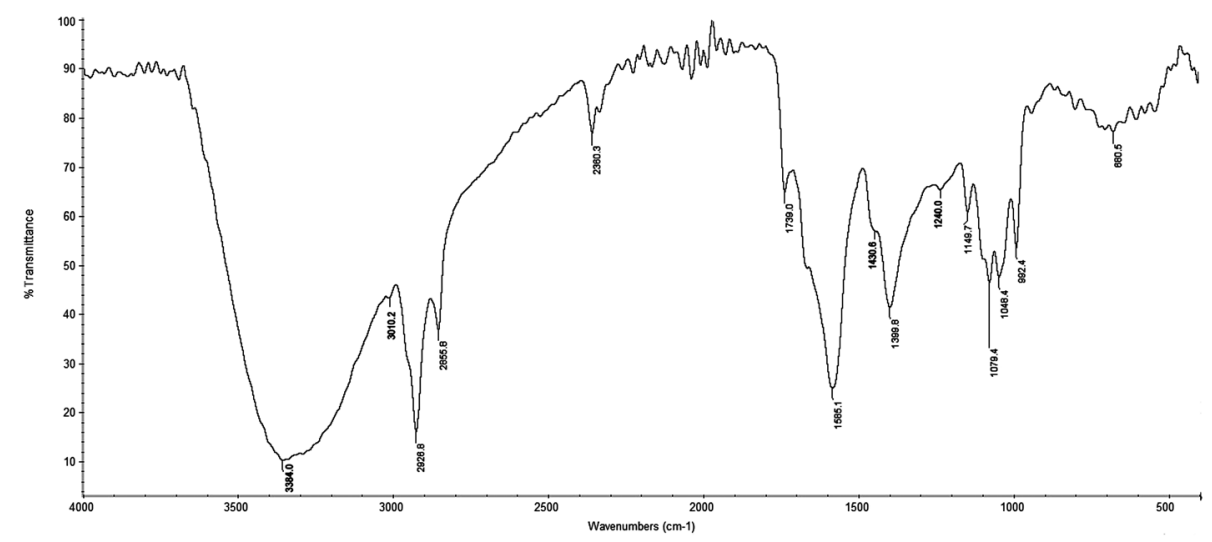

Fig. 2 FT-IR spectrum of crude methanol extract from C. cibarius.

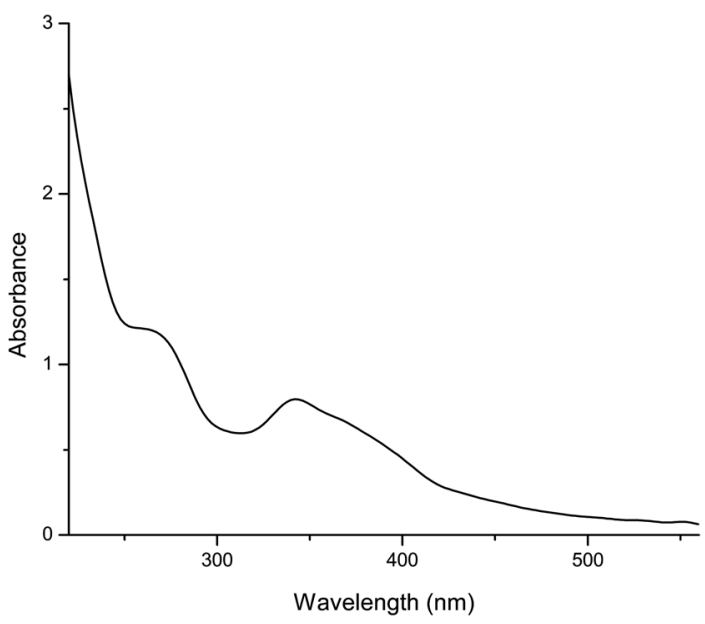

Fig. 3 UV-VIS spectrum of crude methanol extract isolated from C. cibarius.

The UV-Vis spectrum (Fig. 3) of our methanol solution showed two major absorption bands that were characteristic of phenolic compounds, the first one with the absorption maximum in the spectral range between $250 \mathrm{~nm}$ and $285 \mathrm{~nm}$ $\left(\lambda_{\max } 261.8 \mathrm{~nm}\right)$ and the second one with the maximum in the range of $320 \mathrm{~nm}-380 \mathrm{~nm}\left(\lambda_{\max } 340.9 \mathrm{~nm}\right)$. The absorption peaks in the mentioned spectral ranges indicated the presence of phenolic compounds and their derivatives in the mushroom $^{60}$ and were in accordance with previously published data. ${ }^{61,62}$

\subsection{Evaluation of antioxidant activities}

The antioxidant properties were evaluated using the whole extract, which is a complex mixture of phytochemicals (Tables 1 and 2) with additive and synergistic effects. To screen the antioxidant properties, several chemical assays were performed: scavenging activity on DPPH radicals (measuring the formation of the nonradical form of $\mathrm{DPPH}-\mathrm{H}$ in solution, in the presence of a hydrogen-donating antioxidant), reducing power (measuring the conversion of a $\mathrm{Fe}^{3+}$-ferricyanide complex to the $\mathrm{Fe}^{2+}$ form), inhibition of lipid peroxidation in the linoleic acid model system (measuring the formation of conjugated dienes in the system), and the chelating effect on $\mathrm{Fe}^{2+}$ ions. The $\mathrm{Fe}^{2+}$ was monitored by measuring the formation of the $\mathrm{Fe}^{2+}$-ferrozine complex.

The results were normalized and expressed as $\mathrm{EC}_{50}(\mathrm{mg}$ $\mathrm{mL}^{-1}$ ) values which are the effective concentrations of the mushroom extract that are required to show 50\% antioxidant properties (Table 3). A lower $\mathrm{EC}_{50}$ value corresponds to

Table $3 \mathrm{EC}_{50}$ values of the methanol extract from $C$. cibarius in antioxidant properties

\begin{tabular}{|c|c|c|c|c|c|}
\hline & \multicolumn{5}{|c|}{$\mathrm{EC}_{50}{ }^{a}\left(\mathrm{mg}\right.$ extract $\left.\mathrm{mL}^{-1}\right) \pm \mathrm{SEM}$} \\
\hline & C. cibarius & $\alpha$-Tocopherol & $\begin{array}{l}\text { Ascorbic } \\
\text { acid }\end{array}$ & EDTA & $\begin{array}{l}\text { Citric } \\
\text { acid }\end{array}$ \\
\hline Scavenging ability on DPPH radicals & $16.31 \pm 0.95$ & $<0.01$ & $<0.01$ & n.o. ${ }^{b}$ & n.o. \\
\hline Antioxidant activity & $1.21 \pm 0.05$ & $<0.01$ & $0.87 \pm 0.11$ & n.o. & n.o. \\
\hline Reducing power & $7.56 \pm 0.41$ & n.o. & $0.03 \pm 0.003$ & n.o. & n.o. \\
\hline Chelating ability on ferrous ions & $0.64 \pm 0.04$ & n.o. & n.o. & $<0.01$ & n.d. ${ }^{c}$ \\
\hline
\end{tabular}

${ }^{a} \mathrm{EC}_{50}$ value: the effective concentration at which the DPPH radicals were scavenged by $50 \%$; the antioxidant activity was $50 \%$; the absorbance was 0.5 for reducing power; and ferrous ions were chelated by $50 \%$, respectively. $\mathrm{EC}_{50}$ value was obtained by interpolation from linear regression analysis; each value is expressed as mean $\pm \operatorname{SEM}(n=5) .{ }^{b}$ (n.o.) - not observed. ${ }^{c}$ (n.d.) - not detected. 


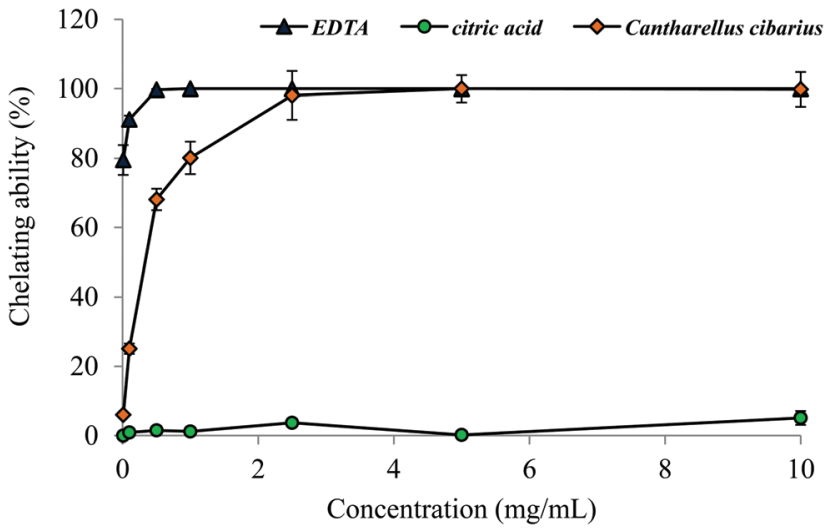

Fig. 4 Chelating ability on ferrous ions of methanol extract from $C$. cibarius. Each value is expressed as mean $\pm \operatorname{SEM}(n=5)$.

higher antioxidant activity of the mushroom extract. $\alpha$-Tocopherol, ascorbic acid, EDTA and citric acid were used for comparison.

With regard to scavenging ability of DPPH radicals, the methanol extract from $C$. cibarius showed scavenging ability as evidenced by its $\mathrm{EC}_{50}$ value of $16.31 \mathrm{mg} \mathrm{mL}^{-1}$ (Table 3 ). It was comparable with the $\mathrm{EC}_{50}$ value $\left(19.65 \pm 0.28 \mathrm{mg} \mathrm{mL}^{-1}\right)$ of the methanol extract from Portuguese wild C. cibarius, ${ }^{14}$ but significantly higher than the $\mathrm{EC}_{50}$ value $\left(2.68 \mathrm{mg} \mathrm{mL}^{-1}\right)$ of scavenging ability of the DPPH radical for the methanol extract from Nigerian wild $C$. cibarius. $^{44}$ Ascorbic acid and $\alpha$-tocopherol are both confirmed as excellent scavengers of DPPH radicals $\left(\mathrm{EC}_{50}<0.01 \mathrm{mg} \mathrm{mL} \mathrm{m}^{-1}\right)$. These are accepted food additives, and used at mg levels in foods.

In our previous studies, the antioxidative properties of polysaccharide extracts of various mushrooms obtained by different extraction procedures were tested. ${ }^{21,34,42,63-65}$ Extracts demonstrated very good scavenging ability on DPPH radicals, among which Phellinus linteus, Ganoderma lucidum, Ganoderma applanatum and Lentinula edodes extracts showed particularly low $\mathrm{EC}_{50}$ values $\left(<0.1 \mathrm{mg} \mathrm{mL}{ }^{-1}\right){ }^{21,34}$

Our $C$. cibarius methanol extract showed a good capacity for inhibition of lipid peroxidation as shown by its low $\mathrm{EC}_{50}$ value $\left(1.21 \pm 0.05 \mathrm{mg} \mathrm{mL}^{-1}\right)$. It was comparable to the $\mathrm{EC}_{50}$ value of ascorbic acid $\left(0.87 \pm 0.11 \mathrm{mg} \mathrm{mL}{ }^{-1}\right)$. $\alpha$-Tocopherol showed

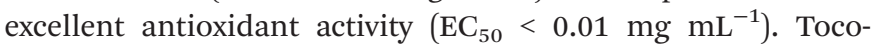
pherol functions as a chain-breaking antioxidant for lipid peroxidation in cell membranes. ${ }^{66}$ A wide range of atherogenic processes have been reported to be influenced by the oxidative modification of low-density lipoproteins (LDLs) and their components. ${ }^{67}$
For reducing power of $C$. cibarius an $\mathrm{EC}_{50}$ value of $7.56 \pm$ $0.41 \mathrm{mg} \mathrm{mL}^{-1}$ was found and it was comparable with the $\mathrm{EC}_{50}$ value, $8.72 \pm 0.03$, of Portuguese wild C. cibarius. ${ }^{14}$ Testing chelating ability, our methanol extract exerted a high potential in chelating on $\mathrm{Fe}^{2+}$ ions (Fig. 4). The chelating ability increased as the concentration increased from 0.01 to $2.5 \mathrm{mg} \mathrm{mL}^{-1}$ and reached a plateau of $98.1-100 \%$ at $2.5-10.0 \mathrm{mg} \mathrm{mL}^{-1}$. At a concentration of $2.5 \mathrm{mg} \mathrm{mL}^{-1}$ the methanol extract showed the same potential in chelating capability of $\mathrm{Fe}^{2+}$ ions as the most potent chelator EDTA (Fig. 4).

Chelation is an important parameter. Iron has several vital functions in the body as oxygen transport, in respiration, and the activities of many enzymes. ${ }^{68}$ However, iron is an extremely reactive metal and possesses the ability to produce reactive free radical species and catalyze oxidative changes in lipids, proteins, and other cellular components. ${ }^{69}$

Antioxidants can exercise their protective properties at different stages of the oxidation process and by different mechanisms. There are two main types of antioxidants, namely, primary (chain breaking, free radical scavengers) and secondary or preventive. Secondary antioxidant mechanisms may include deactivation of metals, inhibition of breakdown of lipid hydroperoxides to unwanted volatile products, regeneration of primary antioxidants, singlet oxygen quenching, etc. ${ }^{70}$ But it should also be kept in mind that antioxidants often act via mixed mechanisms that combine different types of antioxidation. ${ }^{63}$ However antioxidant effectiveness is related to activation energy, rate constants, oxidation-reduction potential, ease with which the antioxidant is lost or destroyed (volatility and heat susceptibility), and antioxidant solubility. ${ }^{71}$

Hence, the results of the antioxidant assays indicated that the antioxidant activity of the methanol extract of $C$. cibarius was achieved through chelating iron as a dominant mechanism compared to hydrogen atom and/or electron transfer mechanisms in the formation of the nonradical forms.

\subsection{In vitro cytotoxic activity}

The cytotoxicity of the $C$. cibarius extract was tested against selected cancer cell lines: human cervix adenocarcinoma HeLa, human myelogenous leukemia K562 and human breast carcinoma MDA-MB-453 cells. Control normal cells were human fetal lung fibroblasts MRC-5 and human lung bronchial epithelial cells BEAS-2B (Table 4).

With $\mathrm{IC}_{50}$ values (concentration of extract that is required for $50 \%$ inhibition in vitro) ranging from 0.231 to $0.307 \mathrm{mg}$ $\mathrm{mL}^{-1}$ following continuous incubation, the examined extract possesses moderate cytotoxicity against all investigated tumor cells. The highest cytotoxicity was found in $\mathrm{K} 562$ cells $\left(\mathrm{IC}_{50}=\right.$

Table 4 Concentrations of the C. cibarius methanol extract which induced $50 \%$ decrease $\left(\mathrm{IC}_{50}\right)$ in malignant and normal cells survival

$\mathrm{IC}_{50}\left(\mathrm{mg} \mathrm{mL}^{-1}\right) \pm \mathrm{SEM}$

\begin{tabular}{lllll}
\hline HeLa & K562 & MDA-MB-453 & MRC-5 & BEAS-2B \\
\hline $0.255 \pm 0.009$ & $0.231 \pm 0.042$ & $0.307 \pm 0.005$ & $0.661 \pm 0.040$
\end{tabular}


$0.231 \mathrm{mg} \mathrm{mL}^{-1}$ ). The $C$. cibarius extract showed higher selectivity in antitumor cell action than to normal control cells. MRC-5 and BEAS-2B cells were significantly less sensitive to cytotoxic action of the investigated extract $\left(\mathrm{IC}_{50}=0.661 \mathrm{mg}\right.$ $\mathrm{mL}^{-1}$ and $0.539 \mathrm{mg} \mathrm{mL}^{-1}$, respectively).

Our extract expressed a significant potential in the chelating ability of $\mathrm{Fe}^{2+}$ ions (Fig. 4). Tumor cells contain more iron than other normal tissues. ${ }^{72}$ It is reasonable to expect that treatment of tumor cells with the $C$. cibarius methanol extract (Table 4) could induce apoptosis in vitro. ${ }^{72,73}$

\subsection{ACE inhibitory activity}

The renin-angiotensin-aldosterone system is a key factor in the maintenance of arterial blood pressure. One of its main components is the angiotensin-converting enzyme (ACE), which is a glycosylated zinc dipeptidyl-carboxypeptidase whose main function is to regulate arterial blood pressure and electrolyte balance through the renin-angiotensin-aldosterone system. ${ }^{74,75}$ Though several synthetic ACE inhibitors are currently in clinical use as antihypertensive agents, ${ }^{74}$ all come with certain adverse effects. ${ }^{75,76}$ Therefore, for safety reasons, interest in identifying food sources as ACE inhibitor has increased.

The crude methanol extract of $C$. cibarius exhibited ACEinhibitory (ACEI) activity in vitro and had an $\mathrm{IC}_{50}$ of $0.063 \pm$ $0.008 \mathrm{mg} \mathrm{mL} \mathrm{mL}^{-1}$ compared to captopril, which had an $\mathrm{IC}_{50}$ value of $0.006 \pm 0.000 \mathrm{mg} \mathrm{mL} \mathrm{m}^{-1}$. Prior to analysis methanol was evaporated from the extract and it was redissolved in $10 \%$ DMSO. As was reported ${ }^{40}$ an alcohol solution is not suitable for sample dissolution because it could interfere with the samples and mask their inhibitory activity, so false positive results could be obtained.

No enzyme inhibition was observed in this study. Moalli et $a .^{77}$ suggested significant differences between in vivo and in vitro kinetics of ACE inhibition. They reported that captopril behaved as a noncompetitive ACE inhibitor in vivo. Other studies have indicated that this inhibitor acts as a competitive or mixed competitive and noncompetitive ACE inhibitor in vitro. Significant differences, however, between in vivo and in vitro experimental conditions suggest that the kinetics of enzyme inhibition in vitro may not necessarily reflect the action of the inhibitor in vivo. ${ }^{77}$

The methanol extract of $C$. cibarius is a complex mixture of primary and secondary metabolites (Tables 1 and 2). Significant concentration of flavonoids (Table 2) as well as the high potential of chelation (Fig. 4, Table 3) may indicate the formation of chelation complexes with the active site of the enzyme as one of the possible mechanisms. ${ }^{75}$ Furthermore, the ACEI activity of different foods and plant extracts rich in flavonoids was earlier demonstrated by in vitro studies, ${ }^{78,79}$ and by in vivo studies in hypertensive rats ${ }^{80,81}$ and humans. ${ }^{82}$

Identification of most potent components in the $C$. cibarius methanol extract as ACE inhibitors necessitates further studies. In addition, further tests in vivo seem to be needed which may more accurately reflect the therapeutic behavior of a potential ACE inhibitor component of the C. cibarius methanol extract.

\subsection{Antimicrobial activities}

Antimicrobial properties of our extract were examined against selected foodborne pathogenic bacteria, Gram-positive species Staphylococcus aureus, Enterococcus faecalis, Bacillus cereus, and Listeria monocytogenes and Gram-negative species Escherichia coli, Salmonella enteritidis, Shigella sonnei, and Yersinia enterocolitica.

Using the disk diffusion method, the ability of bacteria to produce visible growth in the presence of various amounts of mushroom extract was investigated. All tested bacteria were, to a lesser or a greater extent, sensitive to the presence of the $C$. cibarius methanol extract. In general, Gram-positive bacteria have demonstrated a greater sensitivity to the tested extracts than Gram-negative bacteria (Table 5). The diameters of the inhibition zones, determined by the disk diffusion method, ranged from $6.9 \pm 0.2$ to $21.2 \pm 0.2 \mathrm{~mm}$. The highest antibacterial potential was observed towards $E$. faecalis $(21.2 \pm 0.2 \mathrm{~mm})$. Our extract showed significantly higher activity than the com-

Table 5 Antibacterial activity of the methanol extract from C. cibarius determined by the disc diffusion method

Diameter of inhibition zone $(\mathrm{mm})$ including the initial diameter of the $\operatorname{disk}^{a}(6 \mathrm{~mm})$

\begin{tabular}{|c|c|c|c|c|}
\hline \multirow[b]{2}{*}{ Bacterial strain } & \multirow[b]{2}{*}{ Source } & \\
\hline & & C. cibarius & Gentamicin & Tetracycline \\
\hline Staphylococcus aureus & ATCC 25923 & $9.5 \pm 1.0^{c b}$ & $18.0 \pm 0.0^{\mathrm{b}}$ & $30.0 \pm 0.0^{\mathrm{a}}$ \\
\hline Enterococcus faecalis & ATCC 29212 & $21.2 \pm 0.2^{\mathrm{a}}$ & $12.0 \pm 0.0^{\mathrm{c}}$ & $16.0 \pm 0.0^{\mathrm{b}}$ \\
\hline Bacillus cereus & ATCC 10876 & $12.7 \pm 0.4^{\mathrm{b}}$ & $15.0 \pm 1.0^{\mathrm{a}}$ & $12.0 \pm 0.0^{\mathrm{b}}$ \\
\hline Listeria monocytogenes & ATCC 19115 & $9.5 \pm 0.3^{\mathrm{c}}$ & $12.0 \pm 1.0^{b}$ & $15.3 \pm 0.6^{\mathrm{a}}$ \\
\hline Escherichia coli & ATCC 25922 & $8.4 \pm 0.5^{\mathrm{c}}$ & $22.7 \pm 0.6^{\mathrm{a}}$ & $10.7 \pm 0.6^{b}$ \\
\hline Salmonella enteritidis & ATCC 13076 & $6.9 \pm 0.2^{c}$ & $25.0 \pm 0.0^{\mathrm{a}}$ & $21.3 \pm 0.6^{b}$ \\
\hline Shigella sonnei & ATCC 29930 & $7.7 \pm 0.6^{c}$ & $16.7 \pm 0.6^{\mathrm{a}}$ & $11.7 \pm 0.6^{b}$ \\
\hline Yersinia enterocolitica & ATCC 27729 & $7.2 \pm 0.1^{\mathrm{c}}$ & $30.7 \pm 0.6^{\mathrm{a}}$ & $27.0 \pm 0.0^{b}$ \\
\hline Escherichia coli $(0157: \mathrm{H7})$ & ATCC 12900 & $8.1 \pm 0.6^{\mathrm{c}}$ & $22.0 \pm 1.0^{\mathrm{b}}$ & $33.0 \pm 2.0^{\mathrm{a}}$ \\
\hline
\end{tabular}

${ }^{a}$ Data are expressed as mean $\pm \operatorname{SEM}(n=5) .{ }^{b}$ Within the same row, means followed by different letters are significantly different at $\alpha=0.05$ (ANOVA, Tukey's HSD Test). 
Table 6 Antibacterial activity of the methanol extract from $C$. cibarius expressed as MIC (mg mL $\left.{ }^{-1}\right)$ and $M B C\left(\mathrm{mg} \mathrm{mL}^{-1}\right)$ determined by the broth microdilution method

\begin{tabular}{lllc}
\hline Bacterial strain & Source & & C. cibarius \\
\hline Staphylococcus aureus & ATCC 25923 & MIC & $1.25 \pm 0.00^{a}$ \\
& & MBC & $20.0 \pm 0.0$ \\
Enterococcus faecalis & ATCC 29212 & MIC & $0.156 \pm 0.000$ \\
& & MBC & $2.5 \pm 0.0$ \\
Bacillus cereus & ATCC 10876 & MIC & $0.3125 \pm 0.000$ \\
Listeria monocytogenes & ATCC 19115 & MBC & $5.0 \pm 0.000$ \\
& MIC & $0.625 \pm 0.000$ \\
Escherichia coli & ATCC 25922 & MBC & $10.0 \pm 0.0$ \\
Salmonella enteritidis & ATCC 13076 & MBC & $-{ }^{b}$ \\
Shigella sonnei & ATCC 29930 & MBC & - \\
& & MIC & $10.0 \pm 0.0$ \\
Yersinia enterocolitica & ATCC 27729 & MBC & - \\
& & MIC & $20.0 \pm 0.0$ \\
Escherichia coli $(0157: H 7)$ & ATCC 12900 & MIC & - \\
& & MBC & -
\end{tabular}

${ }^{a}$ Data are expressed as mean values of five independent experiments. ${ }^{b}$ - Not achieved.

mercial antibiotics gentamicine and tetracycline, which indicates its antimicrobial potency.

We used the disk diffusion method as a preliminary screening of antibacterial activity. This procedure, however, is not completely reliable and therefore we applied the broth microdilution method for the quantitative determination of MIC, which is based on the color change caused by the enzymatic activity of viable microorganisms. Well defined endpoints appeared as the results of the metabolic activity of bacteria, i.e. TTC reduction (Table 6). The extract inhibited the growth of all tested Gram-positive and Gram-negative bacteria. MBC was achieved only against Gram-positive bacterial strains in the range of $2.5 \pm 0.0-20.0 \pm 0.0 \mathrm{mg} \mathrm{mL} \mathrm{m}^{-1}$. The highest antibacterial potential of the C. cibarius methanol extract was obtained against $E$. faecalis (MIC $-0.156 \pm 0.000 \mathrm{mg} \mathrm{mL}^{-1}$; $\mathrm{MBC}-2.5 \pm$ $0.0 \mathrm{mg} \mathrm{mL} \mathrm{m}^{-1}$ ). Similarly as in the disk diffusion assay, Grampositive bacteria were significantly more susceptible than Gram-negative bacteria.

E. faecalis are normal gut commensals, but are also a common cause of many serious human infections, including urinary tract infections, endocarditis, bacteremia, and wound infections. ${ }^{83}$

Our results indicate a possibly important role of the methanol extract from C. cibarius as a potential bactericidal agent. The fight against $E$. faecalis by antibiotics is sometimes very long and difficult. ${ }^{84}$

\section{Conclusions}

With the increase in life expectancy and increase in lifestyle diseases, nutraceuticals are of particular interest because they can substantially reduce the use of antibiotics. With increasing concerns of consumers about side effects and the presence of synthetic additives in foods, demand for natural alternatives has increased rapidly. ${ }^{85}$

The bioactive properties (antioxidative, cytotoxic, antihypertensive and antibacterial) of Cantharellus cibarius were evaluated using the complete methanol extract, which is a complex mixture of phytochemicals with additive and synergistic effects. The analyzed extract contains very useful phytochemicals among which phenols are the major components, followed by flavonoids, whose content is approximately $86 \%$ of the total phenol content.

The results of the antioxidant assays indicated that antioxidant activity was achieved through chelating iron as a dominant mechanism compared to hydrogen atom and/or electron transfer mechanisms in the formation of the nonradical forms. The high flavonoid levels as found in our extract may help provide protection against oxidative stress induced diseases. Many studies demonstrated that antioxidant properties are due to the presence of flavonoids, hence may be a reason for the high lipid peroxidation inhibition found in the studied extract. $^{86}$

The C. cibarius extract showed a certain selectivity in cytotoxicity on human cervix adenocarcinoma HeLa, breast carcinoma MDA-MB-453 and human myelogenous leukemia K562 in comparison with normal control human fetal lung fibroblasts MRC-5 and human lung bronchial epithelial cells BEAS-2B cells.

In our study ACE inhibitor activity of C. cibarius was reported for the first time. Hypertension is a very common disease that afflicts humans worldwide and is one of the major risk factors for cardiovascular disease. ${ }^{75}$ Synthetic ACE inhibitors, such as captopril and enalapril, are widely used. However, side effects such as cough, angioneurotic edema and deleterious effects in pregnancy have been associated with their use. Therefore, new, natural product-based ACE inhibitors could help to prevent hypertension. They might especially help to prevent preeclampsia and its deleterious effects in pregnancy that seems associated with the use of synthetic ACE inhibitors. ${ }^{87}$

This mushroom presents a promising antihypertensive activity, selective cytotoxicity, antioxidant activities against lipid peroxidation and antibacterial activity in vitro as a possible effective source of nutraceuticals. Further studies in vivo may more accurately demonstrate the possible therapeutic behavior of these compounds.

\section{Conflict of interest}

The authors declare that they have no conflict of interest.

\section{Acknowledgements}

The study was financed by EU Commission project AREA, no. 316004 and the Serbian Ministry of Science and Technological 
Development, project numbers III 46001, III 46010 and III 43004. Human lung bronchial epithelial cells BEAS-2B were kindly provided by professor Dr Leo van Griensven, University of Wageningen.

\section{References}

1 J. Gry, C. Andersson, L. Kruger, B. Lyran, L. Jensvoll, N. Matilainen, A. Nurttila, G. Olafsson and B. Fabech, TemaNord, Nordic Council of Ministers, Denmark, 2012.

2 Z. Yang, The Divine Farmer's Materia Medica: A Translation of the Shen Nong Ben Cao Shou, Blue Poppy Press, 1998.

3 C. Grangeia, S. A. Heleno, L. Barros, A. Martins and I. C. F. R. Ferreira, Food Res. Int., 2011, 44, 1029-1035.

4 S. T. Chang and J. A. Buswell, Curr. Top. Nutraceutical Res., 2003, 1, 257-283.

5 B. A. Wani, R. H. Bodha and A. H. Wani, J. Med. Plants Res., 2010, 4, 2598-2604.

6 P. C. K. Cheung, Nutritional value and health benefits of mushrooms, in Mushrooms as Functional Foods, John Wiley and Sons, Inc., USA, 2008, pp. 71-109.

7 L. Fan, H. Pan, A. T. Soccol, A. Pandey and C. R. Soccol, Food Technol. Biotechnol., 2006, 44, 303-311.

8 U. Lindequist, T. H. S. Niedermeyer and W. D. Julich, eCAM, 2005, 2, 285-299.

9 S. P. Wasser and A. L. Weis, Crit. Rev. Immunol., 1999, 19, 65-96.

10 D. Pilz, L. Norvell, E. Danell and R. Molina, General Technical Report PNW-GTR-576, United States Department of Agriculture (USDA), 2003.

11 G. Straatsma, R. N. H. Konings and L. J. L. D. van Griensven, Trans. Br. Mycol. Soc., 1985, 85, 689-697.

12 P. O'Reilly, First Nature, 2011.

13 E. Danell and F. J. Camacho, Nature, 1997, 385, 303.

14 L. Barros, B. A. Venturini, P. Baptista, L. M. Estevinho and I. C. F. R. Ferreira, J. Agric. Food Chem., 2008, 56, 38563862 .

15 I. Akata, B. Ergonul and F. Kalyoncu, Int. J. Pharm., 2012, 8, 134-138.

16 USDA National Nutrient Database for Standard Reference, Retrieved September 18, 2014 from: http://ndb.nal.usda. gov/ndb/foods/show/2974?qlookup=chanterelle.

17 A. Cieniecka-Rosłonkiewicz, A. Sas, E. Przybysz, B. Morytz, A. Syguda and J. Pernak, Chem. Biodiversity, 2007, 4, 22182224.

18 P. Valentao, P. B. Andrade, J. Rangel, B. Ribeiro, B. M. Silva, P. Baptista and R. M. Seabra, J. Agric. Food Chem., 2005, 53, 4925-4931.

19 Durmitor National Park-UNESCO World Heritage Centre, 1992-2015. Retrieved January 10, 2015 from: http://whc. unesco.org/en/list/100.

20 R. Phillips, Mushrooms and Other Fungi of Great Britain \& Europe, Macmillan, New York, 1979, pp. 227-235.
21 M. Kozarski, A. Klaus, M. Niksic, M. M. Vrvic, N. Todorovic, D. Jakovljevic and L. J. L. D. Van Griensven, J. Food Compos. Anal., 2012, 26, 144-153.

22 L. Barros, P. Baptista and I. C. F. R. Ferreira, Food Chem. Toxicol., 2007, 45, 1731-1737.

23 C. K. Kokate, Pharmacognosy, Nirali Prakasham, Mumbai, India, 2001.

24 J. B. Harborne, Phytochemical Methods: A Guide to Modern Techniques of Plant Analysis, Chapman and Hall Int., New York, 1998.

25 M. Du Bois, K. A. Gilles, J. K. Hamitton, P. A. Reders and F. Smith, Anal. Chem., 1956, 28, 350-356.

26 M. M. Bradford, Anal. Biochem., 1976, 72, 248-255.

27 M. B. Medina, J. Funct. Foods, 2011, 3, 79-87.

28 G. E. Lester, K. S. Lewers, M. B. Medina and R. A. Saftner, J. Food Compos. Anal., 2012, 27, 102-107.

29 C. W. Jin, G. Y. You, Y. F. He, C. Tang, P. Wu and S. J. Zheng, Plant Physiol., 2007, 144, 278-285.

30 Z. Jia, M. Tang and J. Wu, Food Chem., 1999, 64, 555-559.

31 B. P. Klein and A. K. Perry, J. Food Sci., 1982, 47, 941-945.

32 M. Nagata and I. Yamashita, Nippon Shokuhin Kogyo Gakkaishi, 1992, 39, 925-928.

33 P. V. Hung and N. N. Y. Nhi, Int. Food Res. J., 2012, 19, 611615.

34 M. Kozarski, A. Klaus, M. Niksic, D. Jakovljevic, J. P. F. G. Helsper and L. J. L. D. Van Griensven, Food Chem., 2011, 129, 1667-1675.

35 T. C. P. Dinis, V. M. C. Madeira and L. M. Almeida, Arch. Biochem. Biophys., 1994, 315, 161-169.

36 T. Mosmann, J. Immunol. Methods, 1983, 65, 55-63.

37 M. Ohno and T. Abe, J. Immunol. Methods, 1991, 145, 199203.

38 B. Hernandez-Ledesma, J. Pedro, P. J. Martian-Aalvarez and E. Pueyo, J. Agric. Food Chem., 2003, 51, 4175-4179.

39 C. B. Faulds, M. Pérez-Boada and A. T. Martínez, Bioresour. Technol., 2011, 102, 4962-4967.

40 M. M. Belovic, N. M. Ilic, A. N. Tepic and Z. N. Sumic, Food Feed Res., 2013, 40, 11-15.

41 CLSI- Clinical and Laboratory Standards Institute, CLSI document M100-S15. Wayne, PA, USA, 2005.

42 A. Klaus, M. Kozarski, J. Vunduk, N. Todorovic, D. Jakovljevic, Z. Zizak, V. Pavlovic, S. Levic, M. Niksic and L. J. L. D. Van Griensven, Food Res. Int., 2015, 67, 272-283.

43 Easycalculation.com, Statistic, Regression - Calculator. Retrieved January 15, 2015 from: http://easycalculation. com/statistics/regression.php.

44 D. A. Aina, S. G. Jonathan, O. J. Olawuyi, D. O. Ojelabi and B. M. Durowoju, N. Y. Sci. J., 2012, 5, 114-120.

45 P. Manzi, A. Aguzzi and L. Pizzoferrato, Food Chem., 2001, 73, 321-325.

46 M. Naczk and F. Shahidi, J. Pharm. Biomed. Anal., 2006, 41, 1523-1542.

47 L. Barros, M. Duenas, I. C. F. R. Ferreira, P. Baptista and C. Santos-Buelga, Food Chem. Toxicol., 2009, 47, 1076-1079.

48 D. Tura and K. Robards, J. Chromatogr., A, 2002, 975, 71-93. 
49 T. Sakaki, U. Zahringer, D. C. Warnecke, A. Fahl, W. Knogge and E. Heinz, Yeast, 2001, 18, 679-695.

50 T. Bunyapaiboonsri, S. Yoiprommarat, A. Khonsanit and S. Komwijit, J. Nat. Prod., 2008, 71, 891-894.

51 B. S. Moon, I. J. Ryoo, B. S. Yun, K. S. Bae, K. D. Lee, I.-D. Yoo and J.-P. Kim, J. Antibiot., 2006, 59, 735-739.

52 M. D. Sokovic, J. M. Glamoclija and A. D. Ciric, In Tech, 2013, 185-232.

53 J. A. Kim, D. Tay and E. Carcache de Blanco, Phytother. Res., 2008, 22, 1104-1106.

54 M. Alam, S. M. Basha and L. C. Boyd, J. Agric. Food Chem., 2000, 48, 5517-5521.

55 R. M. Hallock, McIlvaine J. Am. Amat. Mycol., 2007, 17, 33-41.

56 B. P. Halpern, J. Nutr., 2000, 130, 910S-914S.

57 E. Danell and D. Eaker, J. Sci. Food Agric., 1992, 60, 333337.

58 J. I. Rangel-Castro and E. Danell, Mycologia, 2002, 94, 190199.

59 M. Mathlouthi and J. L. Koenig, Adv. Carbohydr. Chem. Biochem., 1987, 44, 7-89.

60 M. M. Giusti and R. E. Wrolstad, in Current Protocols in Food Analytical, 2001.

61 B. Matthaus, J. Agric. Food Chem., 2002, 50, 3444-3452.

62 T. Ozen and I. Turkekul, Pharmacogn. Mag., 2010, 6, 89-97.

63 M. S. Kozarski, A. S. Klaus, M. P. Niksic, L. J. L. D. Van Griensven, M. M. Vrvic and D. M. Jakovljevic, Chem. Ind., 2014, 68, 305-320.

64 A. Klaus, M. Kozarski, M. Niksic, D. Jakovljevic, N. Todorovic and L. J. L. D. Van Griensven, LWT-Food Sci. Technol., 2011, 44, 2005-2011.

65 A. Klaus, M. Kozarski, M. Niksic, D. Jakovljevic, N. Todorovic, I. Stefanoska and L. J. L. D. Van Griensven, Int. J. Food Sci. Nutr., 2013, 64, 599-610.

66 P. J. Kanu, K. Zhu, J. B. Kanu, H. Zhou, H. Qian and K. Zhu, Trends Food Sci. Technol., 2007, 18, 599-608.

67 M. Garelnabi, S. Kakumanu and D. Litvinov, Role of Oxidized Lipids in Atherosclerosis, Oxidative Stress and Diseases, John Wiley \& Sons, New York, 2012, pp. 1-13.

68 FAO/WHO, Bangkok, Thailand. Food and Nutrition Division FAO, Viale delleTerme di Caracalla, 00100 Rome, Italy, 2001.

69 J. S. F. Swaran, Oxid. Med. Cell. Longevity., 2009, 2, 191-206.
$70 \mathrm{M}$. H. Gordon, The mechanism of antioxidant action in vitro, in Food Antioxidants, ed. B. J. F. Hudson, Elsevier, Amsterdam, 1990, pp. 1-18.

71 M. S. Brewer, Compr. Rev. Food Sci. Food Saf., 2011, 10, 221247.

72 N. Shterman, B. Kupfer and C. Moroz, Pathobiology, 1991, 59, 19-25.

73 G. Y. L. Lui, P. Obeidy, S. J. Ford, C. Tselepis, D. M. Sharp, P. J. Jansson, D. S. Kalinowski, Z. Kovacevic, D. B. Lovejoy and D. R. Richardson, Mol. Pharmacol., 2013, 83, 179-190.

74 D. Coates, Int. J. Biochem. Cell Biol., 2003, 35, 769-773.

75 L. Guerrero, J. Castillo, M. Quinones, S. Garcia-Vallve, L. Arola, G. Pujadas and B. Muguerza, PLoS One, 2012, 7, e49493.

76 Z. H. Israili and W. D. Hall, Ann. Intern. Med., 1992, 117, 234-242.

77 R. Moalli, R. E. Howell and C. N. Gillis, J. Pharmacol. Exp. Ther., 1985, 234, 372-377.

78 L. Actis-Goretta, J. I. Ottaviani and C. G. Fraga, J. Agric. Food Chem., 2006, 54, 229-234.

79 B. W. N. Balasuriya and H. P. V. Rupasinghe, Funct. Foods Health Dis., 2011, 5, 172-188.

80 M. Quinones, D. Sanchez, B. Muguerza, M. Miguel and A. Aleixandre, Food Res. Int., 2011, 44, 1203-1208.

81 A. J. Gasparotto, F. M. Gasparotto, E. L. B. Lourenco, S. Crestani, M. E. A. Stefanello, M. J. Salvador, J. E. da SivaSantos, M. C. A. Marques and C. A. L. Kassuya, J. Ethnopharmacol., 2011, 134, 363-372.

82 M. Aviram and L. Dornfeld, Atherosclerosis, 2001, 158, 195198.

83 A. L. Kau, S. M. Martin, W. Lyon, E. Hayes, M. G. Caparon and S. J. Hultgren, Infect. Immun., 2005, 73, 2461-2468.

84 M. M. Huycke, D. F. Sahm and M. S. Gilmore, Emerging Infect. Dis., 1998, 4, 239-249.

85 Frost \& Sullivan, Report, 2010, Retreived January 30, 2015 from: http://www.frost.com/prod/servlet/cio/236145272.

86 J. B. Harborne and C. A. Williams, Phytochemistry, 2000, 55, 481-504.

87 W. O. Cooper, S. Hernandez-Diaz, P. G. Arbogast, J. A. Dudley, S. Dyer, P. S. Gideon, K. Hall and W. A. Ray, N. Engl. J. Med., 2006, 354, 2443-2451.

88 B. Tepe, D. Daferera, A. Sokmen, M. Sokmen and M. Polissiou, Food Chem., 2005, 90, 333-340. 